\title{
ACCOUNTING STUDENTS' EXPERIENCE OF AN IMPROVED STRATEGY OF FEEDBACK ON ASSESSMENT
}

\author{
Nerine Stegmann* \\ University of Johannesburg
}

Received: April 2016

\author{
Marelize Malan\# \\ University of Johannesburg
}

Accepted: July 2016

\begin{abstract}
Higher education institutions in South Africa are experiencing the effects of massification and diversification of the student body, necessitating students to take more responsibility for the management of their own learning. The education of chartered accountants in South Africa reflects this reality. Feedback on assignments and formative assessments is regarded as a key mechanism to facilitate students' development as independent learners. The practical logistics of providing one-onone feedback to an ever-increasing number of students necessitate a concerted change in feedback practice. The goal of this article is to report on the experience of undergraduate accounting students regarding the revised and more detailed system of feedback on assignments and formative assessments that was introduced by the authors. The researchers are of the opinion that the questionnaire cannot be tested at other universities, unless the total approach to feedback is instituted and supported. The research is underpinned by the theoretical framework of self-directed learning. Pragmatism and a mixed methods methodology is the relevant research paradigm underlying this inquiry and the concurrent triangulation approach is considered appropriate to this investigation. The study found that students were of the opinion that the new form of feedback on assessment enabled them to identify typical mistakes, recognise their individual strengths and weaknesses, gain from constructive criticism and conduct regular self-assessment. The quantitative inquiry clearly showed that students were overwhelmingly satisfied and impressed with the features of the revised strategy of feedback. However, the peer-assessment feature of the strategy was not received as positively, as students expressed anxiety in assessing their peers. The study has proven that a concerted change in focus could assist in student self-assessment and self-directedness.
\end{abstract}

Keywords

Feedback on student assessment, accounting assessment, accounting education, formative assessment, peer assessment

*Prof N Stegmann is an associate professor in the Department of Accountancy, University of Johannesburg, South Africa [nerines@uj.ac.za].

"Ms M Malan is a senior lecturer in the Department of Accountancy, University of Johannesburg, South Africa. 


\section{INTRODUCTION AND PURPOSE}

The realities faced in higher education globally and in South Africa specifically as embodied through massification, diversification of the student body and consumerisation, beckon for ways to enable students to increasingly take responsibility for their own learning (Hunt \& Tierney, 2006; Steenkamp, Baard, \& Frick, 2012). In addition to the general massification of higher education experienced internationally, higher education institutions ( $H E l s$ ) in South Africa were reduced in 2002 from 36, as found in the 'Apartheid' era, to the current 23. This automatically increased the number of students per institution. Furthermore, the student head-count for South African HEls almost doubled from 495356 to 953373 between 1994 and 2012, with $82 \%$ of these being undergraduate enrolments in 2012 (Council of Higher Education, 2015; Department of Higher Education and Training, 2013). This massification trend is likely to continue in future. Worldwide, the number of students enrolled in higher education is forecast to rise from 130 million in 2010 to 414,2 million by 2030 - an increase of $218 \%$ over 20 years at an annual rate of $10.9 \%$ (Calderon, 2012). Hounsell, McCune, Hounsell and Litjens (2008:54-56) find that these trends lead to modularisation and semesterisation, larger class sizes, higher student to staff ratios and less face-to-face contact in the United Kingdom. Similar trends are observed in the South African higher education (HE) sector, noticeably so in the education of chartered accountants (also called certified public accountants (CPAs) in other parts of the world), as experienced by the authors at their institution.

The reality of large classes and the inability of the system, through lack of physical, financial and human resources and time constraints, to engage appropriately with each individual student as was customary barely a decade ago, necessitate that students take more responsibility for their own learning (Snowball \& Sayigh, 2007). Concurrently with the aforementioned, a shift in the perceptions of teaching originally viewed as an almost linear transmission or delivery of knowledge to a planned series of activities whereby students actively construct their own knowledge and skills, gradually unfolded (Gravett, 2003; SAICA, 2009). Even though there is disagreement about the precise definition of student-centred learning, the core assumptions are active engagement in learning and learners taking responsibility for the management of their own learning (Nicol \& Macfarlane-Dick, 2006:200).

It is generally accepted that feedback on assignments and formative assessments serves as a key mechanism in the 'development and enhancement of learning' (Mutch, 2003:36). Feedback is increasingly seen as a crucial way to facilitate students' development as independent learners who are able to monitor, evaluate, and regulate their own learning (Ferguson, 2011; Higgins, Hartley, \& Skelton, 2002). The link between feedback and learning has long been acknowledged (Hounsell, McCune, Hounsell, \& Litjens, 2006), and the assumption of a relationship between feedback and performance is well established (Bloxham \& West, 2007; Holmes \& Papageorgiou, 2009).

Accounting has been taught very successfully for many years at the authors' institution using a fairly 'traditional' teaching and learning approach encompassing only lectures, assignments and multiple assessment opportunities. Feedback was limited to the grading of assessments and the supply of suggested solutions with mark allocations. After an intensive review of the Department of Accountancy's programmes, a new teaching and learning strategy was adopted that places more emphasis on students having to take responsibility for their own learning with a view to becoming life-long learners. This review was prompted by the release of a competency framework by the South African Institute of Chartered Accountants (SAICA) in 2009 that outlines the 
competencies expected of a Chartered Accountant (SA) at point of entry into the profession. However, feedback mostly continued to be limited to suggested solutions supplemented by a general discussion of the most common student responses. As the authors realised that this approach was unsatisfactory from both the lecturers' and the students' perspective, a concerted endeavour was subsequently made to provide students with more detailed and constructive feedback.

The purpose of this article is to report on the experiences of undergraduate accounting students of a revised and more detailed system of feedback on their formative assessments. Although feedback on learning in $\mathrm{H} \varepsilon$ has been widely researched (compare Adcroft, 2011; Carless, Salter, Yang, \& Lam, 2011; Evans, 2013; Gielen, Dochy, \& Onghena, 2011; Lizzio \& Wilson, 2008; and others), the matter has scarcely featured in recent accounting investigations (Curtis (2011) and Sin \& McGuigan (2013), for example incidentally touch on the issue). The inquiry thus intends to address this pertinent research gap. As mentioned previously, the research is underpinned by the theoretical framework of self-directed learning (De Bruin, Jacobs, Schoeman, \& De Bruin, 2001; Guglielmino, 1977; Nicol \& Macfarlane-Dick, 2006; Sadler, 1998), which postulates that formative assessment is specifically intended to generate feedback on learner/student performance aimed at the improvement and acceleration of learning.

\section{LITERATURE VIEWS ON FEદDBACK, SELF-DIRECTED LEARNING AND PEعR ASSESSMENT}

A study by Nicol (2010:503) proposes "that feedback in mass higher education should be conceptualised as a dialogical and contingent two-way process that involves coordinated lecturer-student and peer-to-peer interaction as well as active learner interaction". Based on this proposal the three concepts that impact prominently on this inquiry, namely feedback, selfdirected learning and peer assessment, will hence be interrogated from a theoretical perspective.

\subsection{Feedback on learning}

Feedback is a generic term for activities such as 'correction, reinforcement, forensic, diagnosis, benchmarking and longitudinal development' (Price, Handley, Millar, \& O'Donovan, 2010:278). Initially, feedback was simply associated with knowledge of results where simple outcomes were classified as either correct or incorrect (Kulhavy, 1977). This focus, which developed out of behaviourist stimulus-response models of learning, is now viewed as antiquated and unduly narrow. According to Sadler (2010:535), the focus in higher education has changed from promoting the memorisation of factual materials to developing students' abilities to produce responses to assessment tasks that are divergent rather than convergent and complex rather than simple.

Shute (2007) states that feedback used in educational contexts is crucial to enhance the knowledge and skill repertoires of students (also compare Bangert-Drowns, Kulik, Kulik, \& Morgan, 1991; Epstein, Lazarus, Calvano, Matthews, Hendel, Epstein, \& Brosvic, 2002; Moreno, 2004; Pridemore \& Klein, 1995). In addition to its proven influence on student achievement, feedback is also acknowledged as a prominent motivator of learning (Higgins et al., 2002; Lepper \& Chabay, 1985). 
Views on feedback generally vary between the cognitivist view and a socio-constructivist view. Evans (2013) found that much emphasis is being placed on the latter framework. "The cognitivist perspective is closely associated with a directive telling approach where feedback is seen as a corrective, with an expert providing information to the passive recipient (71)". Askew and Lodge (2000) characterise the cognitivist-correct view of feedback as a 'gift' from the teacher to the learner, where feedback is a one-way communication.

Within the socio-constructivist paradigm, feedback is seen as facilitative in that it involves the provision of comments and suggestions to enable students to make their own revisions and helps them to gain new understanding through dialogue without dictating what those understandings should be (Archer, 2010 in Evans, 2013:71; Carless et al., 2011). Although the cognitivist and socio-constructivist perspectives seem to be opposites, they should be viewed as reinforcing rather than as dissimilar ends of a continuum when considering the precise nature and emphasis of feedback to support task, individual and contextual needs (Evans, 2013:71-72). Hattie and Timperley (2007) advocate a more moderate view, claiming a continuum between instruction and feedback with feedback and instruction becoming intertwined towards the centre.

In line with the move towards a more constructivist view, the concept 'formative feedback' more accurately symbolises this notion. Formative feedback is seen as valuable and usable information communicated to students/learners with the intention of modifying their thinking and behaviour, contributing towards higher quality learning (Higgins et al., 2002; Shute, 2008:154). Formative feedback may be further delineated as 'multidimensional, non-evaluative, supportive, learnercontrolled, timely, specific, credible, infrequent, contingent, and genuine' in nature (Shute, 2007:2). In a historical review on feedback, Kulhavy and Stock (1989, in Shute, 2008:153) report that effective feedback provides learners/students with verification and elaboration dividends; verification is seen as a judgment of whether an answer is correct or not, and elaboration provides relevant cues to guide learners/students toward the correct answer.

Effective feedback aims to bridge the gap between the learners'/students' actual level of performance and the desired learning outcomes (Evans, 2013; Lizzio \& Wilson, 2008; Sadler, 1998). Vygotsky (1978) and Palinscar (1998) regard feedback as useful if it triggers inner dialogue in students around disciplinary concepts and ideas. Such inner dialogue would lead students to actively decode feedback information, internalising it, comparing it against their own conceptions, using judgements about its qualities and ultimately making improvements in future work (Nicol, 2010:504), thereby bridging the learning gap. The ideal is thus that students 'do something with transmitted information, analyse the message, ask questions about it, discuss it with others, connect it with prior understanding and use this to change future actions' (Nicol, 2010:503). While quality feedback is important, the students' engagement with feedback items is even more essential. Nicol and Macfarlane-Dick (2006:204) highlight a meta-analysis (conducted by Black and Williams in 1998), which confirms that appropriate feedback generates noticeable learning and achievement dividends across all content areas, knowledge and skill domains and levels of education. It could therefore be inferred that learners/students will gain from feedback only to an extent that is commensurate with the effort that goes into producing it (Sadler, 2010:536).

From the lecturer's perspective, guidance is needed on what type of feedback is perceived to be constructive and effective. Nicol and Macfarlane-Dick (2006:205) synthesise seven principles for good feedback practice where feedback is broadly defined as 'anything that might strengthen the students' capacity to self-regulate their own performance'. Good feedback, in their opinion:

1. helps clarify what good performance is (goals, criteria, expected standards); 
2. facilitates the development of self-assessment (reflection) in learning;

3. delivers high quality information to students about their learning;

4. encourages teacher and peer dialogue around learning;

5. encourages positive motivational beliefs and self-esteem;

6. provides opportunities to close the gap between current and desired performance; and

7. generates information for lecturers that can help shape their teaching.

A key component of the success and impact of feedback is the buy-in of students and their participation in their own learning. However, feedback will encourage independent thinking only if students increasingly take responsibility for their own learning - the trademark of selfregulated learning or self-directedness.

\subsection{Learner/student self-directedness}

In view of the fact that the learning strategy adopted by the researchers' department places more emphasis on students having to take responsibility for their own learning with a view to becoming life-long learners, self-directed learning needs focused attention in this endeavour. It is clear that self-directed learning forms the basis for an accounting professional's life-long learning journey. At this point, it should however be clear that self-directedness is primarily motivated by the reality of South African $H E$ necessitating students to take increasing ownership of their own learning and takes precedence over theoretical perspectives. The conspicuous benefit is of course the large body of empirical evidence, mainly from the USA, showing that learners who are more self-directed are more effective, persistent, resourceful, confident and better achievers (Pintrich, 1995; Zimmerman \& Schunk, 2001).

Self-directed learning is defined as 'an active constructive process whereby learners set goals for their learning and monitor, regulate, and control their cognition, motivation and behaviour guided and constrained by their goals and the contextual features of their environment' (Pintrich \& Zusho, 2002:64). It promotes life-long learning (Curtis, 2011; Pacharn, Bay, \& Felton, 2013), a skill highly regarded by the accounting profession in South Africa (SAICA, 2009).

Learner/student self-directedness is manifested in practice in 'the active monitoring and regulation of a number of different learning processes, e.g. the setting of, and orientation towards, learning goals; the strategies used to achieve goals; the management of resources; the effort exerted; reactions to external feedback; the products produced' (Nicol \& Macfarlane-Dick, 2006:199). A self-directed learner/student successfully self-regulates her/his learning and strives to attain goals against which her/his performance can be compared. Such goals are partly defined by criteria, standards and other reference points set for the particular module or course, but also by a student's inner motivation. Feedback provides information about how the student's learning and performance relate to these goals.

As students engage with learning activities and tasks, internal feedback is generated. The more self-directed a student is, the more he/she would be able to use the feedback to improve his/her performance to eventually achieve the desired outcomes (Butler \& Winne, 1995). Such a process requires focused facilitation by lecturers so that students can grow in their ability to self-reflect and self-direct their learning (Tonge \& Willet, 2009:211). The question now arises whether inputs by peers could not perhaps enhance their learning experience further. 


\subsection{Peer assessment}

The desirability of feedback cannot be separated from the practical logistics of its provision, and the number of students has a direct impact on the feedback dialogue. Sadler (2010:536) stresses that feedback should be appropriate but also take account of available resources, of which the scheduled time of lecturers to provide useful feedback to individual students is a pertinent issue. These constraints make peer assessment a logical option to consider in making feedback more effective.

Peer assessment is 'an arrangement in which individuals consider the amount, level, value, worth, quality or success of the products or outcomes of learning of peers of similar status' (Gielen et al., 2011:137). It therefore increases the number of opportunities for feedback dialogue where significant constraints are present ( $\mathrm{Nicol}, 2010)$. Peer assessment has been broadly researched in various disciplines and findings on its effectiveness are consistently positive (Boud \& Falchikov, 2006; Falchikov, 2007; Falchikov \& Goldfinch, 2000; Spiller, 2012; Whitman, 1988). It is seen as an important way of engaging students in the development of their own learning and in the manifestation of self-assessment skills (Cartney, 2010; Davies, 2006; Nicol \& Macfarlane-Dick, 2006; Vickerman, 2009). This concept is confirmed in the work of Boud and Falchikov (2006:402), which states that 'the notion of learning-how-to-learn and becoming a lifelong learner, is that of developing the capacity to be an assessor of learning'.

Nicol (2010:509) mentions three reasons why peer assessment is helpful:

1. With large student numbers, it is impossible for lecturers to provide adequate comments for each individual student. Peers can assist with this task.

2. Peers take over the role of assessor, which helps them to better understand the assessment process.

3. By being exposed to the good and bad assignments of their peers, students should develop the ability to assess the quality of their own work more critically.

Based on the research mentioned above, peer assessment should provide a potentially useful learning opportunity to students in large classes to assist teachers to emphasise the value of assessing the outcomes of learning of peers and to apply it for their own self-directed learning.

\subsection{Synthesis of literature perspectives}

The following conclusions can be drawn regarding the theoretical perspectives generated by the literature review and have specific relevance to this inquiry:

- Massification of higher education has necessitated students to take increasing ownership of their own learning.

- A gradual move away from the cognitivist to the socio-constructivist view of learning has led to feedback playing a more facilitative role, with 'ideal' feedback modifying the students' thinking and behaviour, contributing to higher quality learning.

- The reality of South African $\mathrm{HE}$ necessitates student self-directedness, which promotes lifelong learning, a pervasive skill highly valued by the accounting profession.

- The practical logistics of providing one-on-one feedback to an ever-increasing number of students make peer assessment a desirable additional option. 


\section{RATIONALE UNDERLYING THE RESEARCH}

\subsection{Bachelor of Accounting programme at UJ}

Accounting 200 is a compulsory year module in the second year of the Bachelor of Accounting (BAcc) programme at the University of Johannesburg (UJ). The BAcc programme is designed in consultation with the South African Institute of Chartered Accountants (SAICA) primarily to provide a well-rounded, technically focused education that equips graduates with the technical knowledge, proficiency and pervasive skills needed by the chartered accounting profession (SAICA, 2009). The programme is recognised as the first requirement in the training of a student to eventually practise as a chartered accountant and is designed to equip students to write and pass the Initial Test of Competence (ITC) of SAICA. The teaching and learning strategy implemented by the Department of Accountancy before the feedback project commenced is our next focus.

\subsection{Teaching and learning strategy of the Department of Accountancy}

The Department of Accountancy accentuates a cyclical teaching and learning strategy for each topic or study unit within its four core modules - accounting, financial management, taxation and auditing. There are a number of distinct sequential elements that are implemented for students to gain optimal learning exposure and benefit. The strategy is diagrammatically captured in FIGURE 1.

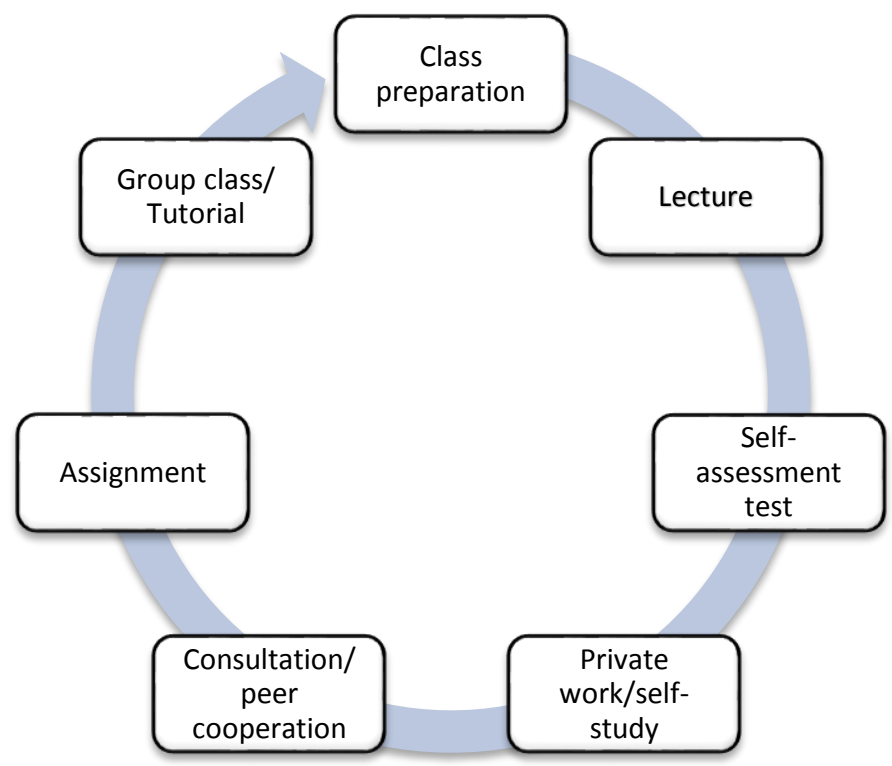

FIGURE 1: Teaching and learning strategy of the Department of Accountancy

Source: Authors'analysis

The diagram emphasises that teaching and learning is not simply an acquisition and transmission activity, but requires students to actively engage in and take responsibility for the management of their learning. Starting with guided class preparation, every element of the strategy is 
interlinked to preceding and subsequent elements. It is further important to note that there are noticeable responsibilities for both the student and the lecturer.

\subsection{Nature of assessment}

Students are introduced to International Financial Reporting Standards (IFRS) and have to grasp the content of these IFRSs conceptually in order to apply them appropriately to case studies and in 'real world' scenarios. To this end, they are expected to participate in six assessments (three per semester) and submit six assignments (three per semester). The assessments are formative by nature, which means that they do 'not cast a final judgement, but inform the student and the lecturer regarding the progress of learning' (University of Johannesburg, 2015:10). The assessment includes written tests (taken under examination conditions) and assignments (done at home or on campus, making use of open access to learning material and other resources). A $40 \%$ or above end of the year progress mark provides a student with access to the last summative assessment opportunity in each module.

\subsection{Feedback on assessment}

Soon after each assignment and assessment, the lecturers provide a suggested solution and at times general verbal comments are made to highlight common problem areas and mistakes. Students are then required to use their private study time (in accordance with the teaching and learning strategy in FIGURE 1) to compare their marked scripts with the suggested solutions and with the feedback provided.

\subsection{Research rationale}

Through individual consultation and discussion with students, it became clear to the lecturers (and authors of this article) that most students do not review their marked scripts nor compare them to the suggested solutions and feedback as outlined in 3.4. The lecturers quickly realised that students might not have the necessary skills to perform such reviews.

\subsection{The feedback on assessment project is born}

It was hence decided to create opportunities for students to engage more incisively with the marked scripts, suggested solutions and feedback provided. This led to the so-called 'feedback on assessment project', which formally commenced during the second semester of 2014 involving students enrolled for the Accounting 200 module (see 3.1). The aim of the project was to introduce students to a more detailed form of feedback and to gauge their experiences.

\section{IMPLEMENTATION OF THE FEEDBACK ON ASSESSMENT PROJECT}

The project broadly consisted of two components: firstly, general feedback (as opposed to feedback tailored to each individual student) was given after assessment opportunities four and five, and, secondly, assignments four and six were peer assessed by the students. TABLE l outlines the components and their implementation during the project. 
TABLE 1: Components of the project and their implementation

\begin{tabular}{|c|c|}
\hline Project component & Implementation \\
\hline \multicolumn{2}{|l|}{ General feedback } \\
\hline $\begin{array}{l}\text { After assessments four and } \\
\text { five, students were provided } \\
\text { with a marked script, solution } \\
\text { and general feedback } \\
\text { comments during a tutorial } \\
\text { class. }\end{array}$ & $\begin{array}{l}\text { Students were requested to actively engage with their marked } \\
\text { script, solution and general feedback comments. They were } \\
\text { guided in self-reflection and through the answering of questions } \\
\text { specifically designed to stimulate inner dialogue and provide } \\
\text { them with a simple process to critically assess future } \\
\text { assessments. }\end{array}$ \\
\hline \multicolumn{2}{|l|}{ Peerfeedback } \\
\hline $\begin{array}{l}\text { After assignment four and six, } \\
\text { students peer assessed two of } \\
\text { their fellow students' } \\
\text { submitted assignments and } \\
\text { provided them with feedback } \\
\text { comments. }\end{array}$ & $\begin{array}{l}\text { In a tutorial class, students had the chance to peer assess two } \\
\text { assignments submitted by their fellow students. They were } \\
\text { provided with a suggested solution and were guided in the } \\
\text { marking process by a tutor. They were also requested to answer } \\
\text { the following two questions regarding their fellow student's } \\
\text { assignment and add their comments: } \\
\text { - How well does the assignment address the issues identified? } \\
\text { - How can the assignment be improved? }\end{array}$ \\
\hline
\end{tabular}

Source: Authors' analysis

\section{AN EMPIRICAL INPUIRY INTO FEEDBACK ON THE ASSESSMENT PROJECT}

\subsection{Empirical research question}

The research question that this inquiry attempts to answer is stated as follows: What are Accounting 200 students' experiences and perceptions of the (new) detailed form of feedback on their formative assessments?

\subsection{Research paradigm, methodology and approach}

Pragmatism (Creswell, 2009; Tashakkori \& Creswell, 2007) is regarded as the relevant research paradigm underlying this inquiry. It is a philosophy introduced by Peirce (1878, in Johnson, Onwuegbuzie, \& Turner, 2007), who believed that in order to conceive anything about an inquiry there is a need to consider the practical bearings that the inquiry might have. A mixed methods methodology, utilising both quantitative and qualitative data collection methods, which considers both subjective and objective knowledge and focuses on 'what works', was therefore applied (Tashakkori \& Creswell, 2007).

The specific mixed methods design considered appropriate to this inquiry is known as the concurrent triangulation approach (Wurtz, 2009). The main features of this approach are that (Creswell, 2008; Wurtz, 2009):

- quantitative and qualitative data collection are concurrent and happen during a single data collection phase (see sections 6.2 and 6.3).

- neither of the data collection methods is given more priority than the other. 
- the two methods are integrated in the interpretation of the findings phase (see section 6.4).

- integration focuses on how the findings from each of the methods correspond with or differ from the primary purpose of complementing and supporting each other.

\subsection{Sampling and data collection}

Purposive sampling (Palys in Given, 2008) was adopted in this inquiry, as the preferred sampling method is tied to the empirical research question (compare section 5.1) and dependent on the context in which the research was undertaken. To gain insight into the experiences and perceptions of formative feedback on their assessments of a group of Accounting 200 students, convenience sampling was considered appropriate. The unit of analysis was a group of Accounting 200 students, and the sampling criteria that were set are that the participants:

- should academically be at least in their second year of study;

- could be of any age or gender;

- must have been enrolled for the Accounting 200 module either as first-time or repeating students on a full-time basis; and

- must have been exposed to the feedback project (as outlined in section 4).

A self-designed questionnaire was administered to these participants in the second semester of the academic year during one of the contact sessions. The questionnaire was based on literature perspectives (section 2) and consisted of four sections and a mixture of closed-and open-ended questions.

- Section one contained questions of a biographical nature that were used in the design of a profile of the participants (see TABLE 2).

- Section two comprised general closed- and open-ended questions aimed at gaining students' perceptions of the feedback project.

- Section three included a number of 5-point Likert scale-type statements and interrogated the participants' perceptions on the effectiveness of the feedback practices. Each of the 18 items utilised a response scale, ranging from 1 (Strongly disagree) to 5 (Strongly agree), with 3 representing a neutra/stance.

- Section four contained two closed- and two open-ended questions and sought to gain information regarding the students' actions based on the feedback they received, if appropriate, and the usefulness of the different kinds of feedback.

\subsection{Ethical considerations}

To maintain individual confidentiality, the participants were assured that any information divulged via the questionnaires would be recorded in an anonymous manner. Participants were also informed that their participation was voluntary and that they had the right to withdraw from the study at any time, should they feel uncomfortable, without prejudice to them. Individual written consent was obtained from all the participants to safeguard the confidentiality of the collected data and their anonymity.

Strategies to maintain the trustworthiness of the data collected via the demographic and perception-based items (specifically questions in sections 1, 2 and 4 - see section 5.3) included the selected credibility, transferability, dependability and confirmability measures originally recommended by Lincoln and Guba (1985). An exhaustive description of the inquiry, its planning 
and implementation, the properties of the participants, the data collection instrument and mixed method of analysis, enhance transferability. A dense description of the methodology employed via the constant comparative method (Jacobs \& Du Toit, 2006) promoted dependability and rigour. The credibility of the research was augmented through a proper interrogation and triangulation of the findings by both researchers, while the original questionnaires were maintained for possible follow-up purposes.

A pilot study involving ten Accounting 200 students (who were also participants) was conducted two weeks before the data collection date to gauge the questionnaire's perceived sight validity. The questions in the questionnaire were based directly on the literature perspectives, which led the researchers to believe that the instrument also displays content validity. This was confirmed when the questionnaire was pre-tested by two Faculty of Education professors, who might be regarded as experts in formative assessment. Feedback from both the group of students and the two education professors was overwhelmingly positive and only marginal fine-tuning of a few questions was necessary.

The reliability coefficient was calculated in line with the responses to the 18 Likert scale items (section 3 of the questionnaire - see 5.3). Reverse coding was applied to the four 'negatively worded' items before the analysis. The Cronbach's alpha value for the 18 items was .841 . This exceeded the researchers' expectations, as according to Rattray and Jones (2007:237), 'Cronbach's $\alpha$ should exceed 0.70 for a developing questionnaire or 0.80 for a more established questionnaire'. This confirmed that the participants' responses have high internal consistency or reliability.

\section{FINDINGS AND DISCUSSION}

\subsection{Profile of the participants}

The demographic profile of the 257 participants is portrayed in TABLE 2. The majority of the participants are female (59\%) and black (69\%), speak an indigenous South African or African language (67\%), are 20 or 21 years of age $(81 \%)$ and are enrolled for this module for the first time $(84 \%)$. Almost two-thirds of the participants $(65 \%)$ are not first generation students, which implies that most of them were not the first members of their families to engage formally in higher education.

TABLE 2: Demographic profile of the participants

\begin{tabular}{llcc}
\hline Profile variable & & $N$ & $\%$ \\
\hline Gender & Female & 152 & 59.1 \\
$(n=257)$ & Male & 105 & 40.9 \\
Ethnic group & Asian/Indian & 29 & 11.3 \\
$(n=257)$ & Black & 178 & 69.3 \\
& Coloured & 10 & 3.9 \\
& White & 37 & 14.4 \\
& Did not say/Other & 5 & 1.2 \\
\hline
\end{tabular}




\begin{tabular}{llcc}
\hline Profile variable & & $N$ & $\%$ \\
\hline Home language & Indigenous & 171 & 66.5 \\
$(n=257)$ & English & 56 & 21.8 \\
& Afrikaans & 23 & 8.9 \\
& Other & 7 & 2.8 \\
Age & $18-19$ years & 23 & 8.9 \\
$(n=257)$ & $20-21$ years & 209 & 81.3 \\
& 22 or older & 10 & 4.0 \\
& Did not say & 15 & 5.8 \\
Repeater status & Repeating & 42 & 16.3 \\
$(n=257)$ & First-time & 215 & 83.7 \\
\hline
\end{tabular}

Source: Authors' analysis

\subsection{Qualitative findings on the new form of feedback}

The participants' perceptions per question were consolidated into a worksheet and then analysed and categorised via the constant comparative method of qualitative data analysis (Jacobs \& Du Toit, 2006, 305-306). Appropriate participants' views per category are quoted below in support of the findings.

The two open-ended questions 'In my opinion, the purpose of feedback should be ...' and 'What, in your view, is the greatest value of feedback? generated a highly positive response from most participants regarding their experiences of the feedback project. Their views are captured in the four categories/themes below.

\subsubsection{Identification and non-repetition of mistakes}

The new form of feedback on assignments and assessments enabled students to identify their mistakes so as not to repeat them in future. Two student quotes confirmed this: 'with adequate feedback, the same errors are seldom repeated'; 'To learn from your mistakes so that you won't make them again'.

\subsubsection{Knowledge of own strengths and weaknesses}

Additional feedback (not just a mark) highlighted individual strengths and weaknesses. Three student views attested to this: 'To know my strengths and weaknesses on a specific question, and how to improve on it'; 'It tells me where / stand ...'; 'A percentage mark does not serve as feedback'.

\subsubsection{Important constructive criticism}

Feedback is regarded as noteworthy constructive criticism from a subject matter expert, or in the words of a participant: 'It teaches me how / should've approached the assessment from an experienced person's point of view (the lecturer)'. 


\subsubsection{Enhancing self-assessment}

The new form of feedback stimulated self-assessment: '/learn from my mistakes and it enlightens me'; 'The purpose of feedback should be to help me assess myself'.

\subsection{Quantitative findings: students' experiences of the new form of feedback}

The participants' responses to the Likert scale items in the questionnaire (section 5.3) were analysed to determine their levels of disagreement or agreement. To this end, the means, modes and standard deviations were calculated for each item and grouped into three categories, namely feedback on assessments, assignments and the project in its totality.

\subsubsection{Student experiences of feedback on assessments}

Four items requested the participants to state their views on the feedback provided on the assessments part of the project, which comprised marked scripts, a memorandum and comments during a tutorial class (compare section 4.). The responses are outlined in TABLE 3.

TABLE 3: Students' experiences of the feedback on assessments

\begin{tabular}{lllll}
\hline Questionnaire number and item & $N=$ & Mean & Mode & SD \\
\hline $\begin{array}{l}\text { 2. Feedback on assessments is important to } \\
\text { facilitate learning. }\end{array}$ & 247 & 4.78 & 5 & 0.585 \\
$\begin{array}{l}\text { 5. Feedback on my assessments has helped me to } \\
\text { clarify things I did not understand. }\end{array}$ & 247 & 4.40 & 5 & 0.784 \\
$\begin{array}{l}\text { 6. My marks improved because of the feedback I } \\
\text { received on my assessments. }\end{array}$ & 246 & 3.54 & 3 & 1.044 \\
$\begin{array}{l}\text { 7. I found the feedback and exercises after } \\
\text { assessments } 4 \text { and } 5 \text { helpful. }\end{array}$ & 246 & 3.97 & 4 & 0.936 \\
Average weighted mean (all 4 items) & 246.5 & 4.17 & &
\end{tabular}

Source: Authors' analysis

TABLE 3 reveals that the students experienced the new form of feedback on their assessments positively and that the feedback is perceived to have contributed to their improved understanding of the content and even advanced their module marks. The mean scores on all four items as well as the average weighted mean can all be pitched on the agreement side of the 5 -point scale, nudging towards strong agreement for two items.

\subsubsection{Student experiences of feedback on assignments}

Six items requested the participants' views on the feedback on assignments part of the project, which entailed peer assessment (compare section 4.). The responses are outlined in TABLE 4. 
TABLE 4: Students' experiences of the feedback on assignments

\begin{tabular}{lllll}
\hline Questionnaire number and item & $N=$ & Mean & Mode & SD \\
$\begin{array}{l}\text { 1. Feedback on assignments is important to } \\
\text { facilitate learning. }\end{array}$ & 249 & 4.41 & 5 & 0.814 \\
$\begin{array}{l}\text { 3. I found the peer assessment on assignments } \\
\text { helpful. }\end{array}$ & 247 & 3.47 & 3 & 1.133 \\
$\begin{array}{l}\text { 4. Feedback on my assignments has helped me } \\
\text { clarify things I did not understand. }\end{array}$ & 246 & 3.96 & 4 & 1.051 \\
$\begin{array}{l}\text { 8. After peer assessing the assignments of fellow } \\
\text { students, I understand the assessment process } \\
\text { better. }\end{array}$ & 245 & 3.62 & 4 & 1.086 \\
$\begin{array}{l}\text { 12. I did N0T find the peer assessment of assignments } \\
\text { helpful [reverse coded }\end{array}$ & 185 & 3.50 & 4 & 1.508 \\
$\begin{array}{l}\text { 13. My marks improved because of the feedback I } \\
\text { received on assignments. }\end{array}$ & 240 & 3.45 & 3 & 0.954 \\
\begin{tabular}{l} 
Average weighted mean (all 6 items) \\
\hline
\end{tabular} & 235.3 & 3.75 & & \\
\hline
\end{tabular}

Source: Authors' analysis

TABLE 4 discloses that the students also experienced the new form of feedback on their assignments positively, although a little less so than on their assessments. Feedback on assignments is perceived as important and helpful; it assisted them in getting a better grasp on the assessment process, while also advancing their module marks. Their responses to the negatively worded item 12 , if the scores are reversed, also attested to the above, although the standard deviation of just more than 1.5 indicates a more diverse spread of responses. The mean scores on all six items as well as the average weighted mean are again all on the agreement side of the 5 -point scale, nudging towards strong agreement for item 1 . It should be noted that a substantial number of students did not feel comfortable assessing their peers; approximately $30 \%$ revealed their anxiety in response to negatively worded item 15 ( 1 / felt anxious to peer assess my fellow students' assignments'), while almost half of them (48.3\%) chose not to respond to the item.

\subsubsection{Student overall experience of the feedback project}

Five items in the questionnaire served the purpose of gaining the participants' overall experience of the feedback project. The responses to these five items are analysed in TABLE 5.

The mean scores on all five items as well as the average weighted mean are all on the agreement side of the 5-point scale with items 16 and 18 nudging towards strong agreement. TABLE 5 thus illustrates that the students' overall experience of the feedback project can be regarded as encouraging. 
TABLE 5: Students' overall experience of the feedback project

\begin{tabular}{|c|c|c|c|c|}
\hline Questionnaire number and item & $N=$ & Mean & Mode & $S D$ \\
\hline $\begin{array}{l}\text { 9. Feedback in the } 2^{\text {nd }} \text { semester assisted me in } \\
\text { reflecting on my studies and progress so far. }\end{array}$ & 242 & 3.96 & 4 & 0.880 \\
\hline $\begin{array}{l}\text { 10. The feedback I received in the } 2^{\text {nd }} \text { semester has } \\
\text { helped me to better identify the gap between my } \\
\text { current and envisaged performance (as was the } \\
\text { case in semester } 1 \text { ) }\end{array}$ & 245 & 4.02 & 4 & 0.914 \\
\hline $\begin{array}{l}\text { 16. The feedback I received in the } 2^{\text {nd }} \text { semester was } \\
\text { NOT helpful at all. [reverse coded] }\end{array}$ & 202 & 4.20 & 5 & 1.165 \\
\hline $\begin{array}{l}\text { 17. I now know how to use feedback and assessment } \\
\text { solutions better to self-assess my work. }\end{array}$ & 240 & 3.82 & 4 & 0.927 \\
\hline $\begin{array}{l}\text { 18. I will be able to self-regulate my work better in } \\
\text { my future studies. }\end{array}$ & 240 & 4.15 & 4 & 0.802 \\
\hline Average weighted mean (all 5 items) & 233.8 & 4.02 & & \\
\hline
\end{tabular}

Source: Authors' analysis

The feedback project enabled the participants to self-assess their performance (better than in the first semester, when the traditional form of feedback was employed), to identify possible gaps in their learning, while they are of the opinion that they would also be more self-regulated (and thus self-directed) in their studies in future. Their responses to the negatively worded item 16 , if the scores are reversed, confirmed this even more pertinently.

\subsection{Mixing the qualitative and quantitative findings}

The mixed methods design utilised for this inquiry (section 5.2) implies that quantitative and qualitative data will be integrated in the interpretation phase with the intention of revealing to what extent the findings from one data collection method complement the findings from the other. TABLE 6 presents a mixture of the main findings generated by the two components regarding the participants' overall experience of the feedback project whereafter interpretations within the context of the research question of the study are made.

TABLE 6: A mixture of the qualitative and quantitative findings of the participants' overall experience of the feedback project

Qualitative findings

The open-ended questions generated a highly positive response from the participants, who are of the opinion that the new form of feedback on assessment enabled them to:

- identify typical mistakes, which they would not repeat in future;

- recognise their individual strengths and weaknesses as accountancy students;

\section{Quantitative findings}

The 18 Likert scale type items also generated highly positive responses from the participants. The feedback project enabled them to:

- self-assess their performance better than when the traditional form of feedback was employed $-72.7 \%$ of the 245 students (who responded) agreed or strongly agreed, culminating in a 4.02 (out of 5 ) weighted average; 


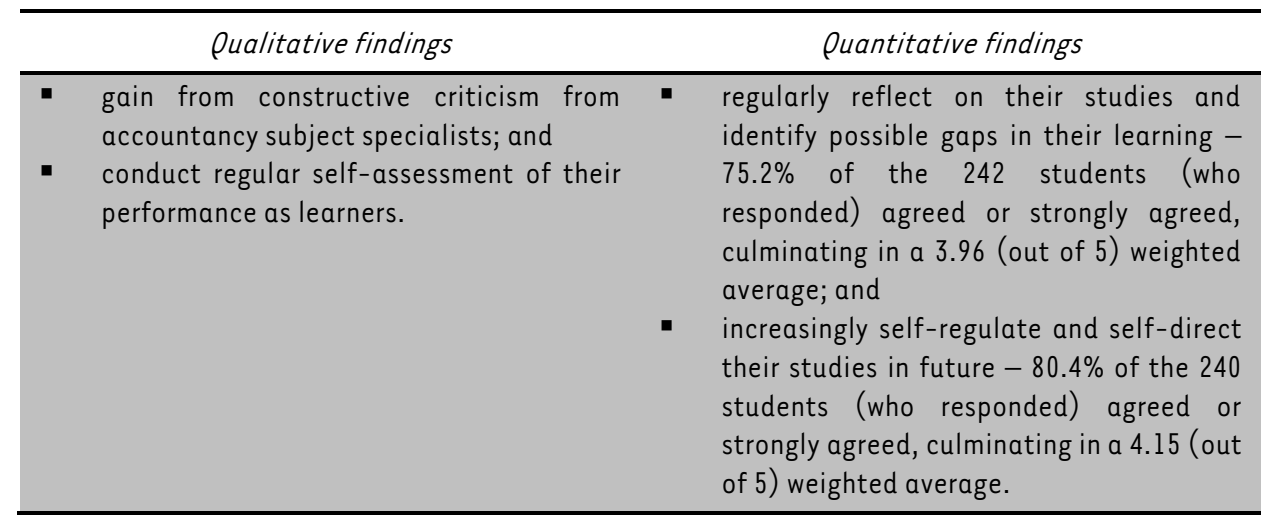

Source: Authors' analysis

The researchers deem that TABLE 6 (as a mixture of qualitative and quantitative perspectives) provides sufficient evidence that the undergraduate accounting students who actively participated in this revised strategy of feedback on their assessments and assignments were overwhelmingly satisfied and impressed with the features of the new strategy.

The peer-assessment feature of the strategy unfortunately elevated the participants' levels of anxiety and thus did not come naturally to them. Literature confirmed (section 2.3) that peer assessment is a useful individual feedback mechanism, especially in large class settings. The implementation of peer assessment in future does require further investigation and the researchers will consider:

- the allocation of more contact time for this kind of feedback (in a 50-minute tutorial, students were required to peer assess two assignments); and

- additional directed implementation of this feedback mechanism by the lecturers.

\section{CONCLUSION}

The purpose of this article is to report on the experiences of a group of second year accounting students who were exposed to a revised and more detailed strategy of feedback on their formative assessments. The research is underpinned by the theoretical framework of self-directed learning, which postulates that formative assessment is specifically intended to generate feedback on learner performance aimed at the improvement and acceleration of their learning.

The new feedback strategy made a markedly positive contribution to the students' capacities for self-reflection, self-assessment and self-directedness. It eventually also contributed to the improvement of their learning performance (end of course marks) in accounting. The latter is perhaps the ultimate test of the practical significance of this feedback strategy in the teaching and learning of accountancy in large classes.

The questionnaire that was developed to test students' perceptions of an integrated approach to feedback in a particular module was repeated in the following years at the same institution and confirmed the findings of this research. The researchers are of the opinion that the questionnaire cannot be tested at other universities, unless the total approach to feedback is instituted and supported. 


\section{Acknowledgement}

The authors greatly appreciate the guidance and assistance provided by Professor Gerrie Jacobs, researcher professor at the Science and Technology Education Department at the University of Johannesburg.

\section{LIST OF REFERENCES}

Adcroft, A. (2011). The mythology of feedback. Higher Education Research \& Development, 30(4), pp. 405-419.

Askew, S. \& Lodge, C. (2000). Gifts, ping-pong and loops - linking feedback and learning. In Feedback for learning. Edited by Askew, S. London: Routledge.

Bangert-Drowns, R.L., Kulik, C.C., Kulik, J.A. \& Morgan, M.T. (1991). The instructional effect of feedback in test-like events. Review of Educational Research, 61, pp. 213-238.

Bloxham, S. \& West, A. (2007). Learning to write in higher education: Students perceptions of an intervention in developing understanding of assessment criteria. Teaching in Higher Education, 12(1), pp. 77-89.

Boud, D. \& Falchikov, N. (2006). Aligning assessment with long-term learning. Assessment \& Evaluation in Higher Education, 31(4), pp. 399-413.

Butler, D.L. \& Winne, P.H. (1995). Feedback and self-regulated learning: A theoretical synthesis. Review of Educational Research, 65(3), pp. 245-281. doi:10.3102/00346543065003245.

Calderon, A. (2012). Massification continues to transform higher education. University World News /ssue No: 237. Available: http://www.universityworldnews.com/article.php?story=201208311553411. (Accessed 13 April 2014).

Carless, D., Salter, D., Yang, M. \& Lam, J. (2011). Developing sustainable feedback practices. Studies in Higher Education, 36(4), pp. 395-407.

Cartney, P. (2010). Exploring the use of peer assessment as a vehicle for closing the gap between feedback given and feedback used. Assessment \& Evaluation in Higher Education, 35(5), pp. 551-564.

Creswell, J.W. (2008). Chapter 3 Choosing a mixed methods design. Available:

http://www.sagepub.com/upm-data/35066_Chapter3.pdf. (Accessed 15 November 2014).

Creswell, J.W. (2009). Research design: Qualitative, quantitative and mixed methods approaches. Thousand Oaks, CA: Sage Publishers.

Council of Higher Education. (2015). Vita/Stats: Public Higher Education, 2012. Available: http://www.che.ac.za/site/default/files/publications/VitalStats\%202012\%20Web.pdf. (Accessed 23 May 2014).

Curtis, S.M. (2011). Formative assessment in accounting education and some initial evidence on its use for instructional sequencing. Journal of Accounting Education, 29(4), pp. 191-211.

Davies, P. (2006). Peer assessment: Judging the quality of students' work by comments rather than marks. Innovations in Education and Teaching International, 43, pp. 69-82.

doi:10.10.1080/14703290500467566. 
De Bruin, K., Jacobs, G.J., Schoeman, W.J. \& De Bruin, G.P. (2001). The factor structure of the Selfdirected Learning Readiness Scale (SDLRS), South African Journal of Higher Education, 15(3), pp. 119-130.

Department of Higher Education and Training. (2013). White Paper for Post-School Education and Training. Available: http://www.dhet.gov/SiteAssets/Latest\%20News/White\%20paper\%20forpostschool\%20education\%20and\%20traning.pdf. (Accessed 3 February 2014).

Evans, C. (2013). Making sense of assessment feedback in higher education. Review of Educational Research, 83(1), pp. 70-120.

Epstein, M.L., Lazarus, A.D., Calvano, T.B., Matthews, K.A., Hendel, R.A., Epstein, B.B. \& Brosvic, G.M. (2002). Immediate feedback assessment technique promotes learning and corrects inaccurate first responses, The Psychological Record, 52, pp. 187-201.

Falchikov, N. (2007). The place of peers in learning and assessment. In Boud, D. \& Falchikov, N (eds.) Rethinking in higher education: Learning for the longer term. London and New York: Routledge. (pp. 128-143).

Falchikov, N. \& Goldfinch, J. (2000). Student peer assessment in higher education: A meta-analysis comparing peer and teacher marks. Review of Educational Research 70(3), pp. 287-322.

Ferguson, P. (2011). Student perceptions of quality feedback in teacher education. Assessment \& Evaluation in Higher Education, 36(1), pp. 51-62.

Gielen, S., Dochy, F. \& Onghena, P. (2011). An inventory of peer assessment diversity. Assessment and Evaluation in Higher Education, 36, pp. 137-155.

Given, L.M. (Ed.) (2008). The Sage Encyclopaedia of qualitative research methods, 2, pp. 697-698. Thousand Oaks, CA: Sage Publishing.

Gravett, S. J. (2003). Teaching and learning: Establishing communities of inquiry and interpretation, in: Gravett, S. J. \& Geyser, H. C. (Eds.), Teaching and learning in higher education. Pretoria: Van Schaik Publishers. (pp. 22-31).

Guglielmino, L.M. (1977). Development of the self-directed learning readiness scale (Doctoral dissertation, University of Georgia). Dissertation Abstracts International, 38, 6467A.

Hattie, J. \& Timperley, H. (2007). The power of feedback. Review of Educational Research 77(1), pp. 81-112.

Higgins, R., Hartley, P. \& Skelton, A. (2002). The conscientious consumer: Reconsidering the role of assessment feedback in student learning, Studies in Higher Education, 27(1), pp. 53-64.

Holmes, K. \& Papageorgiou, G. (2009). 'Good, bad and insufficient': Student expectations, perceptions and uses of feedback. Journal of hospitality, Leisure, Sport and Tourism Education, 8(1), pp. $85-96$.

Hounsell, D., McCune, V., Hounsell, J. \& Litjens, J. (2006). Investigating and enhancing guidance and feedback to undergraduate students. Paper presented at the 3rd Biennial Northumbria/EARL SIG Assessment Conference, Northumbria.

Hounsell, D., McCune, V., Hounsell, J. \& Litjens, J. (2008). The quality of guidance and feedback to students. Higher Education Research \& Development, 27(1), pp. 55-67.

Hunt, J.B. \& Tierney, T.J. (2006). American higher education: How does it measure up for the $21^{\text {st }}$ century? San Jose, CA: The National Centre for Public Policy and Higher Education. 
Jacobs, G.J. \& Du Toit, A.C. (2006). Contrasting faculty quality views and practices over a five-year interval. Quality in Higher Education, 12(3), pp. 303-314.

Johnson, R.B., Onwuegbuzie, A.J. \& Turner, L.A. (2007). Towards a definition of mixed methods research, Journal of Mixed Methods Research, 1(2), pp. 112-133.

Kulhavy, R.W. (1977). Feedback in written instruction. Review of Educational Research, 47, pp. 211 232.

Lepper, M.R. \& Chabay, R.W. (1985). Intrinsic motivation and instruction: Conflicting views on the role of motivational processes in computer-based education. Educational Psychologist, 20, pp. 217-230.

Lincoln, Y. S., \& Guba, E. G. (1985). Naturalistic inquiry. Beverley Hills, CA: Sage.

Lizzio, A. \& Wilson, K. (2008). Feedback on assessment: student's perceptions of quality and effectiveness. Assessment \& Evaluation in Higher Education, 33(3), pp. 263-275.

Moreno, R. (2004). Decreasing cognitive load for novice students: Effects of explanatory versus corrective feedback in discovery-based multimedia. Instructional Science, 32, pp. 99-113.

Mutch, A. (2003). Exploring the practice of feedback to students. Active learning in higher education, 4(1), pp. 24-38.

Nicol, D. (2010). From monologue to dialogue: improving written feedback processes in mass higher education. Assessment \& Evaluation in Higher Education, 35(5), pp. 501-517.

Nicol, D.J. \& Macfarlane-Dick, D. (2006). Formative assessment and self-regulated learning: a model and seven principles of good feedback practice. Studies in Higher Education, 31(2), pp. 199-218.

Pacharn, P., Bay, D. \& Felton, S. (2013). The impact of a flexible system of students' motivation, performance and attitude. Accounting Education, 22(2). doi: 1080/09639284.2013.765292.

Palinscar, A.S. (1998). Social-constructivist perspectives on teaching and learning. Annual Review of Psychology, 49, pp. 345-375.

Pintrich, P.R. (1995). Understanding self-regulated learning. San Francisco, CA, Jossey-Bass.

Pintrich, P.R. \& Zusho, A. (2002). Student motivation and self-regulated learning in the college classroom. In J.C. Smart \& W.G. Tierney (Eds.) Higher Education: handbook of theory and research (vol. XVII). New York: Agathon Press.

Price, M., Handley, K., Millar, J. \& O'Donovan, B. (2010). Feedback: all that effort, but what is the effect. Assessment \& Evaluation in Higher Education, 35(3), pp. 277-289.

Pridemore, D.R. \& Klein, J.D. (1995). Control of practice and level of feedback in computer-based instruction. Educational and Technology research and development, 39(4), pp. 27-32.

Rattray, J. \& Jones, M.C. (2007). Essential elements of questionnaire design and development, Journal of Clinical Nursing, 16, pp. 234-243. doi: 10.1111/j.1365-2702.2006.01573.x.

Sadler, D.R. (1998). Formative assessment: revisiting the territory. Assessment in Education, 5(1), pp. $77-84$.

Sadler, D.R. (2010). Beyond feedback: developing student capability in complex appraisal.

Assessment \& Evaluation in Higher Education, 35 (5), pp. 535-550.

Shute, V.J. (2007). Focus on formative feedback. ETS Research Report No. RR-07-11, Princeton, NJ.

Shute, V.J. (2008). Focus on formative feedback. Review of Educational Research, 78, pp. 153-189. doi: 10.3102/0034654307313795. 
Sin, S., \& McGuigan, N. (2013). Fit for Purpose: A Framework for Developing and Assessing Complex Graduate Attributes in a Changing Higher Education Environment. Accounting Education: an international journal, 22(6), pp. 522-534.

Snowball, J.D. \& Sayigh, દ. (2007). Using the tutorial system to improve the quality of feedback to students in large class teaching. South African Journal of Higher Education, 21(2), pp. 321-333.

South African Institute of Chartered Accountants (SAICA) (2009) Competency Framework. Competencies of a Chartered Accountant (SA) at entry point to the profession. Available: http://www.saica.co.za/Portals/0/Learners Student Documents/Integritas-292277pdf. (Accessed 3 February 2014).

Spiller, D. (2012). Assessment matters: Self-Assessment and peer assessment. The University of Waikato, New Zealand. Available:

http://www.waikato.ac.nz/tdu/pdf/booklets/9_SelfPeerAssessment.pdf. (Accessed 27 March 2014).

Steenkamp, L.P., Baard, R.S. \& Frick, B.L. (2012). A holistic investigation into a tutor programme in first-year Financial Accounting. Meditari Accountancy Research, 20(1), pp. 68-87.

Tashakkori, A., \& Creswell, J.W. (2007). The new era of mixed methods. Journal of Mixed Methods Research, 1(1), pp. 3-7.

Tonge, R., \& Willett, C. (2009). Learning to think: Using coursework to develop higher-order academic and practitioners skills among final year accounting students. Accounting Education: An International Journal, 18(2), pp. 207-226.

Vickerman, P. (2009). Student perspectives on formative assessment: An attempt to deepen learning? Assessment and Evaluation in Higher Education, 34, pp. 221-230.

Vygotsy, L.S. (1978). Mind in Society. Cambridge, MA: Harvard University Press.

Whitman, N.A. (1988). Peer teaching: To teach is to learn twice. ASHE-ERIC Higher Education Report No. 4. Available: http://files.eric.ed.gov/fulltext/ED305016.pdf. (Accessed 27 March 2014).

Wurtz, K. (2009). Using mixed methods research to analyze surveys, Chaffey College. Available: http://www.chaffey.edu/research/ir_pdf_files/presentations/other/0809-mixedmethods.pdf. (Accessed 15 January 2015).

Zimmerman, B.I. \& Schunk, D.H. (Eds.). (2001). Self-regulated learning and academic achievement: Theoretical perspectives. Hillsdale, NJ: Erlbaum. 